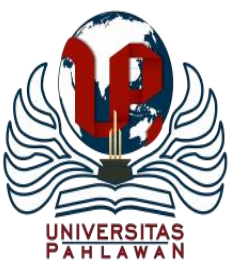

Edukatif : Jurnal Ilmu Pendidikan Volume 1 Nomor 2 Tahun 2019 Halaman 80-87

EDUKATIF: JURNAL ILMU PENDIDIKAN

Research \& Learning in Education

https://edukatif.org/index.php/edukatif/index

\title{
PERBEDAAN KEMAMPUAN KOLABORASI DAN HASIL BELAJAR MATEMATIKA SISWA KELAS 4 SD MENGGUNAKAN MODEL PEMBELAJARAN NUMBERED HEAD TOGETHER DAN TEAMS GAMES TOURNAMENT
}

\author{
Pindi Darma Hutama1, Stefanus Christian Relmasira ${ }^{2}$, Agustina Tyas Asri Hardini
}

Progam Studi Pendidikan Guru Sekolah Dasar, Universitas Kristen Satya Wacana ${ }^{123}$

e-mail : pindidarmahutama15@gmail.com ${ }^{1}, \underline{\text { srelmasira@uksw.edu }}{ }^{2}, \underline{\text { tyas.asri@ } \text { staff.uksw.edu }^{3}}$

\begin{abstract}
Abstrak
Penelitian ini bertujuan untuk mengetahui perbedaan dari kemampuan kolaborasi dan hasil belajar pada penerapan pembelajaran Matematika siswa kelas 4 SD menggunakan pembelajaran cooperative learning tipe Numbered Head Together dan Teams Game Tournament. Subjek dari pelaksanaan penelitian ini adalah siswa kelas 4A yang berjumlah 34 dan siswa kelas 4B yang berjumlah 34 siswa yang berasal dari SD N 16 Purwodadi. Desain dari pelaksanaan penelitian ini adalah eksperimen semu. Berdasarkan hasil penelitian diketahui pembelajaran yang menggunakan model Teams Games Tournament lebih efektif dibandingkan pembelajaran yang menggunakan model Numbered Head Together. Hal tersebut dapat dilihat dari data yang diperoleh berupa hasil uji analisis nilai Asymp. Sig. (2-tailed) adalah 0,023. Maka 0,023 < 0,05 sehingga Ho ditolak sedangkan Ha diterima. Perbedaan kemampuan kolaborasi dan hasil belajar antara model Teams Games Tournament dan Numbered Head Together dikarenakan pada pembelajaran yang menerapkan model Teams Games Tournament sangat mengandalkan kerjasama dalam mengatasi masalah yang diberikan oleh guru sehingga siswa lebih sering berinteraksi dengan siswa yang lain dan dapat meningkatkan kemampuan diri dalam memahami materi melalui interaksi dengan siswa yang lain.
\end{abstract}

Kata Kunci: Numbered Head Together, Teams Games Tournament, Kemampuan Kolaborasi, Hasil Belajar

\begin{abstract}
This study aims to acknowledge the differences in collaboration skills and learning outcomes on the application of Mathematics learning in 4th grade students using Numbered Head Together type cooperative learning and Teams Game Tournament. The subjects of the implementation of this study were 34 students of 4A grade and 34 students of 4B grade from SD N 16 Purwodadi. The design of this research is a quasiexperimental one. Based on the results of the study, it is known that learning using the Teams Games Tournament model is more effective than learning using the Numbered Head Together model. This can be seen from the data obtained in the form of the Asymp value analysis test results. Sig. (2-tailed) is 0.023 . Then $0.023<0.05$ so Ho is rejected while $\mathrm{Ha}$ is accepted. The differences in collaboration skills and learning outcomes between the Teams Games Tournament and Numbered Head Together models caused by learning that applies the Teams Games Tournament model relies heavily on cooperation in overcoming problems given by the teacher so that students interact more frequently with other students and can improve their ability to understand material through interaction with other students.
\end{abstract}

Keywords: Numbered Head Together, Teams Games Tournament, Collaboration, Learning Results

@Edukasi: Jurnal Ilmu Pendidikan FIP UPTT 2019

$\triangle$ Corresponding author :

Address : Kauman Selatan, Purwodadi, Grobogan, Jawa Tengah

Email : pindidarmahutama15@gmail.com

ISSN 2656-8063 (Media Cetak)

Phone : 08562748349 
81 Perbedaan Kemampuan Kolaborasi dan Hasil Belajar Matematika Siswa Kelas 4 SD Menggunakan Model Pembelajaran Numbered Head Together dan Teams Games Tournament - Pindi Darma Hutama, Stefanus Christian Relmasira, Agustina Tyas Asri Hardini

\section{PENDAHULUAN}

Menurut Permendikbud Nomor 21 Tahun 2016 yang berisi mengenai standar isi menjelaskan bahwa pembelajaran Matematika merupakan mata pelajaran yang hasilnya dapat menunjukkan sikap positif, meliputi: logis, cermat dan teliti, jujur, bertanggung jawab, dan tidak mudah menyerah dalam menyelesaikan permasalahan sebagai bentuk kebiasaan dalam inkuiri dan eksplorasi pada muatan pembelajaran mata pelajaran Matematika di sekolah dasar. Mengenai standar isi yang sudah menjelaskan bahwa Matematika pada jenjang sekolah dasar dapat melatih siswa untuk berfikir secara logis, cermat, dan teliti, bersikap jujur, memiliki rasa bertanggung jawab, dan tidak mudah menyerah dalam kehidupan sehari - hari sebagaimana gambaran terhadap sikap positif yang diharapkan dari pembelajaran Matematika pada jenjang sekolah dasar.

Dalam penerapannya pada kehidupan sehari-hari, Matematika sangat erat hubunganya dengan kehidupan manusia. Segala hal tidak dapat terlepas dari Matematika. Menurut Susanto (2015:7) Matematika adalah ilmu yang pemikirannya menggunakan nalar untuk menyelesaikan masalah dan mempunyai peran penting dalam IPTEK. Pembelajaran Matematika dapat membuat siswa untuk belajar sedikit cara dalam menyelesaikan permasalahan. Pentingnya mempelajari Matematika dikarenakan banyak hal yang menjadi masalah dalam kehidupan yang cara penyelesaiannya dengan menggunakan Matematika. Dalam pelaksanaannya, pemilihan model pembelajaran haruslah tepat, pemilihan model pembelajaran yang tepat dapat membuat siswa lebih mudah untuk menangkap materi pembelajaran yang disampaikan oleh guru. Model pembelajaran merupakan suatu kerangka konseptual yang dapat digunakan untuk mencapai tujuan/kompetensi pembelajaran yang sudah dirumuskan, dan sebagai pedoman dalam suatu proses pembelajaran karena berisi langkah/sintak untuk pelaksanaan pembelajaran yang sistematis (Mawardi, 2018:29).

Pemilihan model pembelajaran yang tepat untuk digunakan selama proses pembelajaran dapat memudahkan siswa untuk mengatur kelas dan mampu membuat siswa untuk lebih mudah mengerti dalam menangkap materi yang telah disampaikan oleh guru. Model pembelajaran yang dapat digunakan dalam penyampaian materi adalah model pembelajaran kooperatif yang dapat membuat suasana pembelajaran menjadi aktif atau student center. Rini \& Mawardi (2015:103) mengungkapkan bahwa penggunaan model kooperatif mampu menjadikan siswa bekerja secara mandiri untuk mencari pengetahuan sendiri dari berbagai sumber belajar di sekitarnya. Tipe model pembelajaran kooperatif yang dapat digunakan adalah model Numbered Head together (NHT). Menurut Rahmawati 2015:42) model pembelajaran NHT adalah model pembelajaran yang berorientasi kepada siswa. Pembelajaran di kelas yang menerapkan model pembelajaran NHT dapat menekankan langkah pembelajaran yang interaktif, terutama terhadap antar siswa dalam kelompok kecil.

Selain model pembelajaran NHT, model pembelajaran kooperatif yang dapat digunakan untuk memfasilitasi pembelajaran Matematika adalah model pembelajaran Kooperatif Tipe Teams Games Tournament (TGT). Model pembelajaran ini sangat tergantung pada kemampuan siswa dalam menjawab pertanyaan dari guru, kemampuan kolaborasi siswa dengan teman dalam tim sangat berpengaruh terhadap hasil yang didapat oleh siswa dan timnya. Penerapan model pembelajaran TGT dalam memfasilitasi siswa untuk menangkap materi pembelajaran merupakan penerapan pembelajaran yang membuat siswa dapat menyelesaikan permasalahan dengan berkelompok dan tournament (Putra, 2015:145). 
82 Perbedaan Kemampuan Kolaborasi dan Hasil Belajar Matematika Siswa Kelas 4 SD Menggunakan Model Pembelajaran Numbered Head Together dan Teams Games Tournament - Pindi Darma Hutama, Stefanus Christian Relmasira, Agustina Tyas Asri Hardini

Ketika pelaksanaanya, pembelajaran lebih mendorong siswa untuk dapat saling berinteraksi dengan teman dalam kelompoknya. Langkah pembelajaran yang diterapkannya pun juga mendorong siswa untuk mampu dalam penyelesaian masalah yang dihadapi secara individu maupun dalam kelompoknya.

Penerapan model pembelajaran Numbered Head Together dan Teams Games Tournament dalam pembelajaran membentuk kelas besar menjadi kelompok kecil yang dapat saling bekerjasama. Pada pelaksanaan pembelajaran, tidak lepas dari pembelajaran yang mengandalkan kelompok-kelompok kecil untuk menyelesaikan permasalahan yang telah disampaikan oleh guru. Siswa juga dapat berlatih untuk berkomunikasi dengan baik antar siswa. Melatih kepercayaan dirinya juga bagian dari manfaat yang didapat dari penerapan model pembelajaran diatas. Hasil yang didapatkan setelah pelaksanaan membentuk siswa yang aktif dan interaktif antar siswa, gemar berdiskusi dalam penyelesaian masalah dalam pembelajaran.

\section{Dalam pelaksanaan pembelajaran} Cooperatif Learning, siswa sangat mengandalkan interaksi dan komunikasi antar siswa untuk pemecahan masalah. Interaksi dalam pembelajaran dapat terjadi karena adanya kelompok-kelompok kecil yang bertugas untuk dapat menyelesaikan masalah yang sudah diberikan oleh guru. Kegiatan berkomunikasi dan berkerja sama dengan anggota kelompok disebut sebagai kemampuan kolaborasi yang dimiliki oleh siswa. Desain pembelajaran dengan penerapan kemampuan kolaborasi digambarkan dengan suasana pembelajaran yang dapat menumbuhkan para siswa untuk bekerjasama dalam kelompok-kelompok kecil untuk mencapai tujuan yang sama. Kemampuan kolaborasi bertujuan agar siswa dapat membangun pengetahuannya melalui dialog, saling membagi informasi sesama siswa dan guru sehingga siswa dapat meningkatkan kemampuan mental pada tingkat tinggi. Menurut Sulhan (2006:80) bahwa tujuan dari pembelajaran kolaborasi adalah sebagai berikut: 1) Memaksimalkan proses kerjasama yang berlangsung secara alamiah di antara para siswa. 2) Menciptakan lingkungan pembelajaran yang berpusat pada siswa, kontekstual, terintegrasi, dan bersuasana kerjasama. 3) Menghargai pentingnya keaslian, kontribusi, dan pengalaman siswa dalam kaitannya dengan bahan pelajaran dan proses belajar. 4) Memberi kesempatan kepada siswa menjadi partisipan aktif dalam proses belajar. 5) Mengembangkan berpikir kritis dan keterampilan pemecahan masalah. 6) Mendorong eksplorasi bahan pelajaran yang melibatkan bermacammacam sudut pandang. 7) Menghargai pentingnya konteks sosial bagi proses belajar. 8) Menumbuhkan hubungan yang saling mendukung dan saling menghargai di antara para siswa, dan di antara siswa dan guru. 9) Membangun semangat belajar sepanjang hayat.

Capaian pemahaman materi yang diperoleh oleh siswa dapat dilihat dari hasil belajar siswa yang didapatkan melalui tes. Menurut Slameto (2010:2) hasil belajar merupakan suatu proses perubahan tingkah laku sebagai hasil dari interaksi dengan lingkungannya untuk dapat memenuhi kebutuhan hidupnya. Dengan mengetahui hasil belajar siswa, guru dapat mengetahui sampai mana tingkat kemampuan dari siswa. Selain itu, dengan mengetahui hasil belajar dari siswa guru juga dapat mengevaluasi siswa yang mendapat hasil belajar yang kurang baik. Hasil belajar yang diperoleh guru dengan menganalisis sebelum pemberian pembelajaran dan sesudah pemberian pembelajaran.

Dengan memperhatikan hal yang sudah dituliskan diatas, maka pelaksanaan penelitian akan terfokus pada perbandingan model pembelajaran kooperatif tipe Numbered Head Together dan Teams Games Tournament terhadap 
83 Perbedaan Kemampuan Kolaborasi dan Hasil Belajar Matematika Siswa Kelas 4 SD Menggunakan Model Pembelajaran Numbered Head Together dan Teams Games Tournament - Pindi Darma Hutama, Stefanus Christian Relmasira, Agustina Tyas Asri Hardini

kemampuan kolaborasi dan hasil belajar siswa kelas 4 SD. Oleh karena itu, penulis dapat melakukan penelitian yang berjudul "Komparasi Model Pembelajaran Kooperatif TIpe Numbered Head Together dan Teams Games Tournament ditinjau dari Kemampuan Kolaborasi dan Hasil Belajar Siswa Kelas 4 SDN 16 Purwodadi”. Hasil penelitian ini nantinya akan menjadi acuan bagi guru untuk memilih model yang relevan untuk diterapkan dalam proses pembelajaran, khususnya dalam pembelajaran Matematika bangun datar.

\section{METODE PENELITIAN}

Jenis penelitian yang digunakan adalah Quasi Experimental Research atau Penelitian Eksperimen Semu. Menurut Slameto (2015:123) menjelaskan bahwa penelitian eksperimen adalah suatu penelitian yang objektif, sistematis dan terkontrol untuk memprediksi kejadian, yang bertujuan untuk menyelidiki sebab-akibat, dengan mengekspos satu atau lebih kelompok eksperimen dan satu atau lebih kondisi eksperimen. Menurut Sugiyono (2014:116) eksperimen kuasi atau ekperimen semu dapat digunakan apabila mengalami kesulitan dalam mendapatkan subjek sebagai kelompok kontrol yang benar-benar dapat mengontrol variabel-variabel luar yang mempengaruhinya. Pelaksanaan penelitian eksperimen ini dilaksanakan di SDN 16 Purwodadi yang terletak di Kecamatan Purwodadi Kabupaten Grobogan. Jumlah siswa dari masing-masing kelas adalah 34 siswa. Materi yang akan diterapkan dalam penelitian ini mengenai: Bangun datar dan hubungan bilangan akar pangkat dua. Langkah penelitian dilakukan dengan beberapa tahap. Tahap pertama kelas dilakukan pretes untuk menguji kemampuan awal siswa dalam kelompok eksperimen dan control. Langkah kedua kelas diberikan perlakuan, pada kelas eksperimen diberikan model pembelajaran Teams Games Tournament sedangkan pada kelas control diberikan dengan menerapkan model Numbered Head Together.

Teknik dalam pengumpulan data melalui tes dan nontes. Pada pengambilan data melalui tes, siswa diberikan soal Pre-test untuk mengetahui kemampuan awal sebelum diberikan perlakuan yang berbentuk soal pilihan ganda dan post-test untuk mengukur perubahan yang terjadi setelah pemberian perlakuan. Sedangkan teknik non tes menggunakan wawancara, lembar observasi, angket, dan studi dokumentasi. Soal yang digunakan sebagai soal menguji tingkat kemampuan siswa adalah soal yang telah di validitas dan reliabilitas. Dari 40 soal yang dibuat oleh peneliti terdapat 26 soal yang valid dan memiliki nilai reliabilitas 0,891 yang artinya tergolong baik.

Teknik analisis data menggunakan analisis deskriptif, uji normalitas, uji homogenitas, sebagai prasyarat sebelum dilakukan uji beda rata-rata dan uji hipotesis. Hipotesis dari penelitian ini adalah:

$\mathrm{H}_{0}$ : Hasil belajar Matematika dan kemampuan kolaborasi siswa menggunakan model pembelajaran TGT tidak lebih tinggi atau signifikan dibandingkan dengan hasil belajar dan kemampuan kolaborasi siswa dengan menggunakan model NHT pada siswa kelas 4 SD Negeri 16 Purwodadi.

Ha: Hasil belajar Matematika dan kemampuan kolaborasi siswa menggunakan model pembelajaran TGT lebih tinggi atau signifikan dibandingkan dengan hasil belajar dan kemampuan kolaborasi siswa dengan menggunakan model NHT pada siswa kelas 4 SD Negeri 16 Purwodadi.

Uji normalitas terhadap data dilakukan dengan tujuan untuk mengetahui apakah sebaran data pada kedua kelompok berdistribusi normal atau tidak. Pengujian normalitas data dilakukan 
84 Perbedaan Kemampuan Kolaborasi dan Hasil Belajar Matematika Siswa Kelas 4 SD Menggunakan Model Pembelajaran Numbered Head Together dan Teams Games Tournament - Pindi Darma Hutama, Stefanus Christian Relmasira, Agustina Tyas Asri Hardini

dengan uji One-Sample Kolmogorov-Smirnov Test dengan bantuan SPSS 20 for Windows. Dasar dari pengambilan keputusan pengolahan data berdistribusi normal dengan persyaratan nilai Probabilitas (Asymp. Sig 2-tailed) > 0,05 dan uji yang dilakukan selanjutnya adalah uji parametrik.

Jika nilai Asymp. Sig 2- tailed < 0,05 maka data dinyatakan tidak normal. Jika data yang didapat tidak normal maka uji yang dilakukan adalah uji Nonparametrik dengan menggunakan Mann whitney $U$.

Uji homogenitas digunakan untuk mengetahui apakah dua atau lebih kelompok data sampel berasal dari populasi yang memiliki variansi yang sama atau tidak. Pengolahan data menggunakan ilia dari siswa di kelompok eksperimen dan kontrol. Kedua kelompok dinyatakan homogen dengan ketentuan nilai probabilitas/signifikansi $>0,05$. Pengolahan data untuk mengetahui kedua kelompok homogen atau tidak menggunakan SPSS 20 for Windows.

Setelah melakukan uji prasyarat dengan uji normalitas dan homogenitas. Selanjutnya dilakukan uji beda dengan Uji Mann whitney $U$. Uji beda yang dilakukan untuk menganalisis perbedaan model pembelajaran Numbered Head Together dan Teams Games Tournament ditinjau dari kemampuan kolaborasi dan hasil belajar Matematika. Kedua model memiliki perbedaan jika nilai Asymp. Sig. (2-tailed) < 0,05. Apabila nilai Asymp. Sig. (2-tailed) > 0,05 maka dapat dinyatakan antara kelas eksperimen dan kontrol tidak memiliki perbedaan. Jika kelas dinyatakan terdapat perbedaan maka hipotesis Ho ditolak dan Ha diterima, sebaliknya jika nilai Asymp. Sig. (2tailed) $>$ 0,05 maka hipotesis Ho diterima dan $\mathrm{Ha}$ ditolak.

\section{HASIL DAN PEMBAHASAN PENELITIAN}

Dalam pelaksanaan, sebelum melakukan pembelajaran guru terlebih dahulu membuat
Rencana Pelaksanaan Pembelajaran yang didalamnya meliputi materi pembelajaran bangun datar serta hubungan bilangan kuadrat dan akar pangkat dua. Pelaksanaan pembelajaran dilakukan di kelas eksperimen dan kontrol. Siswa dalam kelas eksperimen berjumlah 34 dan siswa di kelas kontrol berjumlah 34. Dalam pelaksanaannya peneliti didampingi oleh guru kelas sebagai observer. Penerapan pembelajaran pada kelas eksperimen menggunakan model Teams Games Tournament sedangkan pada kelas kontrol menggunakan model Numbered Head Together. Pelaksanaan pembelajaran di kelas eksperimen dan sudah sesuai Rencana Pelaksanaan Pembelajaran yang telah disusun. Kendala pada pelaksanaan penelitian adalah pada pertemuan pertama dikelas eksperimen, siswa menjadi gaduh kemudian masalah dapat diselesaikan dengan penerapan aturan pada permainan.

Dari data yang telah diperoleh dalam penelitian ini yaitu data Pretest dan Posttest terhadap hasil belajar Matematika tersaji dalam tabel 1.

Tabel 1

Tabel Komparasi Hasil Belajar Kelompok Eksperimen dan Kontrol

\begin{tabular}{|l|l|l|l|}
\hline \multirow{2}{*}{$\begin{array}{l}\text { Tahap } \\
\text { Pengukuran }\end{array}$} & \multicolumn{2}{|l|}{ Rerata skor kelompok } & \multirow{2}{*}{ Keterangan } \\
\cline { 2 - 3 } & Eksperimen & Kontrol & Selisih \\
\hline Pretest & 79 & 78,91 & 0,09 \\
\hline Posttest & 82,94 & 79,44 & 3,5 \\
\hline
\end{tabular}

Berdasarkan hasil dari komparasi rata-rata nilai dari yang tertulis di tabel 1, rata-rata skor pretest antara sebelum mendapatkan perlakuan memiliki perbedaan sebesar 0,09. Sedangkan untuk rata-rata posttest yang diperoleh di kelas eksperimen dan kontrol setelah diberikan perlakuan adalah sebesar 3,5. Adapun data dari diagram komparasi data pada kelas eksperimen dan kelas kontrol tersaji dalam gambar 1 .

Dari data yang telah ditampilkan dalam tabel 1 dapat dikatakan bahwa sebelum pemberian 
85 Perbedaan Kemampuan Kolaborasi dan Hasil Belajar Matematika Siswa Kelas 4 SD Menggunakan Model Pembelajaran Numbered Head Together dan Teams Games Tournament - Pindi Darma Hutama, Stefanus Christian Relmasira, Agustina Tyas Asri Hardini

perlakuan baik dalam kelas eksperimen maupun kelas kontrol sudah terdapat perbedaan dari hasil belajar namun dengan nilai rata-rata yang rendah yaitu sebesar 0,09. Perbedaan sangat jelas terlihat ketika kelas eksperimen dan kontrol sama-sama sudah diberikan perlakukan, perbedaan rata-rata yang didapat adalah sebesar 3,5. Walaupun kedua kelas pada kelas eksperimen dan kontrol samasama mengalami kenaikan. Namun, pada kelas eksperimen mengalami kenaikan yang sangat signifikan.

Sedangkan untuk data dari kemampuan kolaborasi dibagi kedalam 3 skala yaitu: dengan nilai 0-40 siswa belum mampu berkolaborasi, 4170 siswa sudah mulai mampu berkolaborasi, dan 71-100 siswa sudah mampu berkolaborasi. Data siswa dapat diperoleh dengan memberikan angket terhadap kelas keseluruhan siswa dalam kelas eksperimen dan kelas kontrol. Hasil dari angket kelas eksperimen dan kontrol terdapat di tabel 2.

Tabel 2

Hasil Angket Kemampuan Kolaborasi

\begin{tabular}{|l|l|l|l|l|}
\hline Kelas & $\begin{array}{l}\text { Belum } \\
\text { Mampu }\end{array}$ & $\begin{array}{l}\text { Mulai } \\
\text { mampu }\end{array}$ & $\begin{array}{l}\text { Sudah } \\
\text { Mampu }\end{array}$ & Total \\
\hline Eksperimen & 0 & 2 & 32 & 34 \\
\hline Kontrol & 0 & 5 & 29 & 34 \\
\hline
\end{tabular}

Dari tabel 2 dapat dilihat bahwa keseluruhan siswa tidak terdapat data yang menunjukkan bahwa terdapat siswa yang belum mampu untuk berkolaborasi. Namun, data menunjukkan adanya perbedaan dari kemampuan yang mulai mampu dengan kemampuan yang sudah mampu. Dari tabel 1 menunjukan bahwa pada kelas eksperimen menunjukkan tingkat kemampuan sudah mampu dalam berkolaborasi lebih tinggi dibandingkan pada kelas kontrol.

Berdasar dari hasil uji normalitas pretest untuk kelompok eksperimen dan kelompok kontrol diperoleh nilai Asymp. Sig (2-tailed) berturut turut adalah 0,023 dan 0,001 . Hasil uji normalitas posttest kelompok eksperimen dan kontrol diperoleh nilai nilai Asymp. Sig (2-tailed) berturut turut adalah 0,005 dan 0,000. Oleh karena nilai signifikansi Asymp. Sig (2- tailed) < 0,05 maka dapat disimpulkan bahwa data pretest dan posttest dari kelompok eksperimen dan kontrol tidak berdistribusi normal.

Berdasarkan uji homogenitas melalui Test of Homogeneity of Variances dengan bantuan SPSS 20 for Windows, diperoleh nilai signifikansi 0,011 untuk pretest, dan 0,358 pada posttest. Karena nilai signifikansi pretes-pretes dan postespostes antar kelompok eksperimen dan kontrol berturut-turut 0,011 dan $0,358>0,05$, maka dapat disimpulkan bahwa yang digunakan dalam penelitian adalah homogen. Setelah uji prasyarat telah terpenuhi, dilakukan uji beda rata-rata pada tahap pretes dan postes antara kelompok eksperimen dan kontrol.

Uji beda penelitian dilakukan menggunakan Mann Whitney Test dengan bantuan SPSS 20 for Windows, dengan ketentuan apabila nilai Asymp. Sig. (2-tailed) < 0,05 maka terdapat perbedaan, namun jika nilai Asymp. Sig. (2-tailed) $>0,05$ maka tidak terdapat perbedaan rata-rata yang signifikan. Uji beda dilakukan menggunakan hasil posttest pada kelas eksperimen dan kelas kontrol. Pengolahan data dapat dilihat pada tabel 3.

Tabel 3

\section{Hasil Uji Beda Rata-rata Posttest dengan Mann-Whitney $U$}

\begin{tabular}{|l|l|}
\hline Test Statistics & Hasil Belajar \\
\hline Mann-Whitney U & 395.000 \\
Wilcoxon W & 990.000 \\
Z & -2.271 \\
Asymp. Sig. (2-tailed) & .023 \\
\hline
\end{tabular}

Dari tabel hasil uji beda rata-rata posttest dengan Mann-Whitney $U$ menunjukkan hasil signifikansi/probabilitas Asymp. Sig. (2-tailed) sebesar $0,023<0,05$. Maka dari itu dapat 
86 Perbedaan Kemampuan Kolaborasi dan Hasil Belajar Matematika Siswa Kelas 4 SD Menggunakan Model Pembelajaran Numbered Head Together dan Teams Games Tournament - Pindi Darma Hutama, Stefanus Christian Relmasira, Agustina Tyas Asri Hardini

disimpulkan bahwa terdapat perbedaan rata-rata yang signifikan antara kelompok eksperimen yang mendapat perlakuan dengan model Teams Games Tournament dibandingkan dengan kelompok kontrol yang mendapat perlakuan dengan model Numbered Head Together.

Pengambilan keputusan hasil penelitian ini dilakukan dengan uji hipotesis berdasarkan MannWhitney $U$ dari hasil tes yang telah dilakukan. Apabila nilai Asymp. Sig. (2-tailed) < 0,05 maka Ho ditolak dan Ha Diterima. Sebaliknya apabila nilai Asymp. Sig. (2-tailed) >0,05 maka Ho diterima dan Ha ditolak. Hipotesis yang diuji dalam penelitian ini dirumuskan sebagai berikut:

$\mathrm{H}_{0}$ : Hasil belajar Matematika dan kemampuan kolaborasi siswa menggunakan model pembelajaran TGT tidak lebih tinggi atau signifikan dibandingkan dengan hasil belajar dan kemampuan kolaborasi siswa dengan menggunakan model NHT pada siswa kelas 4 SD Negeri 16 Purwodadi.

Ha: Hasil belajar Matematika dan kemampuan kolaborasi siswa menggunakan model pembelajaran TGT lebih tinggi atau signifikan dibandingkan dengan hasil belajar dan kemampuan kolaborasi siswa dengan menggunakan model NHT pada siswa kelas 4 SD Negeri 16 Purwodadi.

Hasil Mann Whitney Test menunjukkan nilai Asymp. Sig. (2-tailed) sebesar 0,023 < 0,05. Maka Ho ditolak dan Ha diterima. Sehingga dapat disimpulkan bahwa terdapat perbedaan keefektifan yang signifikan antara model pembelajaran Teams Games Tournament dibandingkan dengan Numbered Head Together terhadap kemampuan kolaborasi dan hasil belajar siswa kelas 4 dalam pembelajaran Matematika. Perbedaan diperoleh karena dalam pembelajaran yang menggunakan model Teams Games Tournament pada segi kemampuan kolaborasi sangat terikat, antar anggota memiliki hubungan yang saling ketergantungan dalam penyelesaian masalah dibandingkan dengan model Numbered Head Together. Dari seringnya berinteraksi siswa menjadi lebih memahami materi dan mampu membuat hasil belajar pada kelompok eksperimen lebih tinggi dibandingkan dengan kelompok kontrol.

\section{KESIMPULAN}

Hasil penelitian ini menunjukkan bahwa setelah dilakukannya analisis data pada uji MannWhitney $U$ diketahui nilai Asymp. Sig. (2-tailed) adalah 0,023 maka 0,029<0,05 sehingga Ho ditolak dan $\mathrm{Ha}$ diterima. Sehingga dari hasil tersebut diketahui bahwa Kemampuan Kolaborasi dan hasil belajar Matematika menggunakan model pembelajaran Teams Games Tournament lebih efektif dari model pembelajaran Numbered Head Together di kelas 4 SDN 16 Purwodadi Kecamatan Purwodadi Kabupaten Grobogan. (Placeholder1)

\section{DAFTAR PUSTAKA}

Mawardi. (2018). Merancang Model dan Media Pembelajaran. Scholaria, 26-40.

Permendikbud (2016) Nomor 21 Tahun 2016 Tentang standart Isi Pendidikan

Putra, F. G. (2015). Eksperimentasi Model Pembelajaran Kooperatif Tipe Teams Games Tournament (TGT) Berbantuan Software Cabri 3d ditinjau dari Kemampuan Koneksi Matematis Siswa. Jurnal Pendidikan Matematika, 143-154.

Rini, R. \&. (2015). Peningkatan Keterampilan Proses Saintifik dan Hasil Belajar Siswa Kelas 4 SDN Slungkep 02 Tema Peduli Terhadap Makhluk Hidup Menggunakan Model Problem Based Learning. Scholaria, 103-113.

Slameto. (2010). Belajar dan Faktor - Faktor Yang mempengaruhi Belajar. Jakarta: Rineka Cipta. 
87 Perbedaan Kemampuan Kolaborasi dan Hasil Belajar Matematika Siswa Kelas 4 SD Menggunakan Model Pembelajaran Numbered Head Together dan Teams Games Tournament - Pindi Darma Hutama, Stefanus Christian Relmasira, Agustina Tyas Asri Hardini

Slameto. (2015). Metodologi Penelitian dan Inovasi Pendidikan. Salatiga: Satya Wacana University Press.

Sugiyono. (2014). Metode Penelitian Pendidikan (Pendekatan Kuantitatif, Kualitatif dan $R \& D)$. . Bandung: CV. Alfabeta.

Sulhan. (2006). Pembangunan Karakter pada Anak. Jakarta: Manajemen Press.

Susanto, A. (2013). Teori Belajar dan Pembelajaran di Sekolah Dasar. Jakarta: Prenada Media Group.

Susanto, A. (2015). Teori Belajar dan Pembelajaran di Sekolah Dasar. Jakarta: Prenada Media. 